terminology leads us to look for factors causing a difference between variation within and between groups; a kin selection model leads us to look for relatedness; and a game theory model leads us to look for frequency dependence and non-additive fitness interactions.

If this is right, the argument is not about what the world is like, or even about how we should model it (that is, what simplifying assumptions are adequate to explain it), but about what words we should use to explain our model. Is the trait group model an example of group selection or kin selection? Is the game theory model an example of group selection or individual selection?

For several reasons, I think the authors' approach to these questions is confusing. First, they are misleading for historical reasons. For example, when Price and I proposed our model of animal fighting, we were combating the then prevalent idea, supported by no less figures than Julian Huxley and Konrad Lorenz, that ritualized fighting behaviour had evolved for the good of the species. We tried to explain it by individual selection, not between-species selection. Essentially, we were arguing about what is an appropriate model of the world. It is therefore confusing to accept our model, but rename it group selection.

A second reason why the book is confusing is that, although the authors argue for pluralism, they are not themselves pluralists: for them, the only right way to describe a model is in group selection language. Any attempt to calculate the behaviour of a model by estimating the fitness of individuals is condemned as "fallacious averaging" (although Wilson himself carried out just such an averaging process in his original trait group model). It is "fallacious" because it detracts attention from the role of grouplevel processes (which, for them, include all interactions between individuals). The result of this bias is that it gives the impres-

\section{Science book prize}

Jared Diamond, professor of physiology at the University of California Los Angeles School of Medicine, has won the 1998 Rhône-Poulenc science book prize for Guns, Germs and Steel: The Fates of Human Societies (Norton/Vintage; for a review see Nature 386, 339; 1997). This makes him the only author to have won the prize twice (his previous success was The Third Chimpanzee). What's more, Guns, Germs and Steel was also awarded this year's Pulitzer prize for general non-fiction (see Nature 392, 750; 1998). Other shortlisted authors for the $£ 10,000$ Rhône-Poulenc prize, which was announced last week at the Science Museum in London, were David Deutsch (The Fabric of Reality; Allen Lane, 1997), Richard Fortey (Life; Knopf), Ernst Mayr (This Is Biology; Belknap, 1997) and Simon Singh (Fermat's Last Theorem; Walker, 1997). sion the authors think that more than semantics is at issue.

Finally, and perhaps most important, they seem to confuse semantic and empirical issues. There are important empirical issues. For example, fascinating experiments by Michael Wade, Charles Goodnight and others show that selection between groups (and even between two-species communities) can be more effective than individual selection in producing change. Sober and Wilson describe these experiments, although they seem curiously uninterested in the underlying mechanisms. In discussing Wade's results they say only, in a footnote, "the reasons... are too technical to be treated in this book".

There follow two chapters concerned with the evolution of human societies. The emphasis is on the competition between human groups, and the role of social norms in guiding the behaviour of individual members of such groups. Because social norms can homogenize the behaviour of groups, the result is that such groups evolve properties ensuring group survival, just as individuals evolve traits ensuring individual survival. I found these chapters the most rewarding section of the book. The essential point is that higher-level entities (for example, individuals carrying many genes, or societies comprising many individuals) will evolve characteristics favouring the success of the group, provided there are processes that reduce within-group selection. In human groups, the most important such process is the homogenization of behaviour by social norms.

The final part of the book discusses human altruism and the motives that cause it. Do people help others because they think they will get pleasure from doing so (hedonism), or because they have an ultimate desire to help another (true altruism)? Sober and Wilson argue that evolutionary biology can shed light on this problem. They do not say that human traits that evolved by individual selection are hedonistic, and those that evolved by group selection are truly altruistic. Their argument is more subtle than that. They start by reviewing psychological and philosophical attacks on the question, and decide it has not been decisively answered. Their approach is to take a specific example, parental care, and argue that it increases biological fitness, and that the most effective proximate mechanism for generating parental care is altruism. It is a kind of reverse engineering argument. Such arguments are used in biology, but usually as a first step in a physiological investigation. For example, an effective proximate mechanism for bird migration would be a magnetic sense: this has led people to seek direct evidence for such a sense. It is a lot harder to seek direct evidence for mechanisms underlying true altruism. I am not really competent to judge this final part of the book; indeed, I am not sure I understood the distinction between hedonistic and altruistic motives for helping others in the first place.

This book should carry a health warning. Read critically, it will stimulate thought about important questions. Swallowed whole, its effects would be disastrous. John Maynard Smith is in the School of Biological Sciences, University of Sussex, Falmer, Brighton BN1 9QG, UK.

\section{New edition}

A second edition of John Maynard Smith's Evolutionary Genetics has recently been published by Oxford University Press ( $£ 50$, \$95, hbk; $\mathfrak{1} 19.95, \$ 39.95$, pbk). When the first edition was reviewed in Nature 339, 107 (1989), R. C. Lewontin wrote: "When... a specialized subject is treated by an expert... the changes in the intellectual structure, the problems and the methods of the field can be seen. John Maynard Smith's new book is a model example."

\section{Per ardua ad Stockholm}

\section{Wish l'd Made You Angry Earlier: Essays on Science, Scientists, and Humanity \\ by Max Perutz \\ Cold Spring Harbor Laboratory Press: 1998. Pp. 354. $\$ 39$}

\section{Walter Gratzer}

Speaking at a memorial symposium for A. Michelson, Einstein related the following anecdote: he had, he said, once asked Michelson why, when the velocity of light was already known with adequate precision, he was continuing to measure it with ever greater accuracy. "Because," Michelson had replied, "I get so much fun out of it". "Das finde ich wunderbar," was Einstein's verdict.

The parallel to Max Perutz's 60-year devotion to the red protein, haemoglobin, is not exact of course, for the deeper he has dug into its workings, the more rewarding the lessons that have emerged, and his work stands now as one of the pinnacles of this century's achievements. The pleasure he has drawn from his quest shines through this lifeaffirming selection of his writings, and he quotes with approval Noël Coward's dictum: "Work is fun. There is no fun like work."

The centrepiece of this collection is Perutz's account of his experiences during the Second World War, when, in the company of thousands of desperate refugees from the horrors unfolding in Germany, and of Italian chefs and waiters who had lived peaceably in Britain for decades, he was incarcerated on the Isle of Man and then deported to Canada. The ageing blimp who commanded the camp was heard to remark that he had had no idea so many of these 


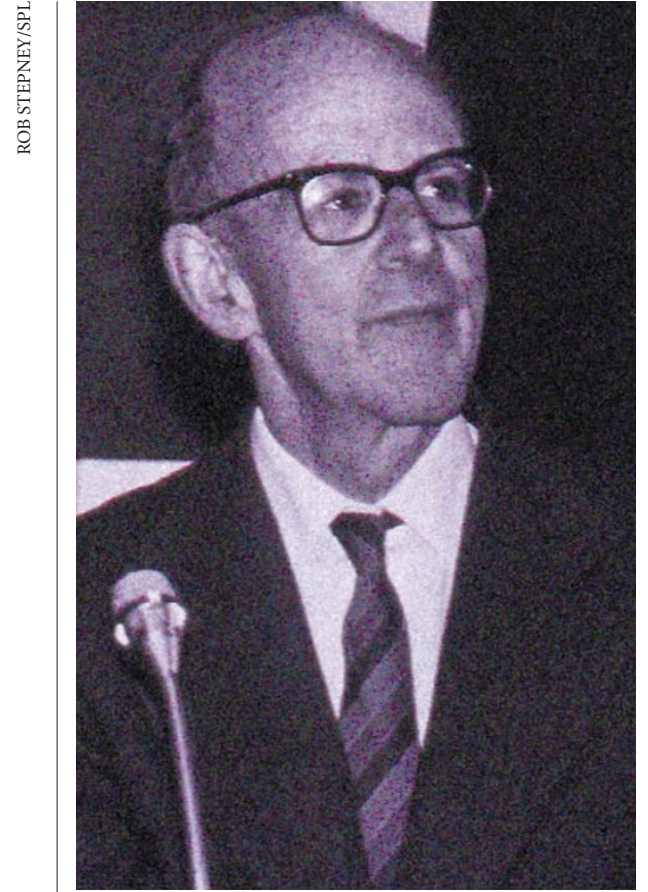

Max Perutz: extraordinary historical grasp.

Nazis were Jews. A ship, the infamous Arandora Star, was torpedoed, and most of the internees, confined below decks, were drowned. Perutz relates the harrowing experience of one Italian survivor, later professor of Italian at the University of Cambridge, who told it to him.

Perutz, eager to play his part in the war, was eventually rescued through the intervention of J. D. Bernal, and was drawn into a comically ill-starred project, conceived by the eccentric inventor Geoffrey Pike, to construct floating airstrips of reinforced ice in the Atlantic Ocean. He eventually returned to Cambridge and his haemoglobin crystals.

Perutz's favourite scientists, vividly portrayed in his pages with many good anecdotes, include the two great masters of his craft: the crystallographers W. L. Bragg, his admired mentor who started it all, and Dorothy Hodgkin. Another friend is François Jacob, whose outlook, civilized and humane, as his writings reveal, is so reminiscent of Perutz's own.

Perutz's benevolence deserts him only in the face of injustice, pomposity or casuistry. Here for instance is how he deftly slips the knife into Richard Lewontin, who proffers the oracular assertion that "Darwin's theory of evolution by natural selection is obviously [sic] nineteenth-century capitalism writ large, and his immersion in the social relations of a rising bourgeoisie had an overwhelming effect on the contents of his theory": "Marxism may be discredited in Eastern Europe," Perutz observes, "but it still seems to flourish at Harvard". He is infuriated by the school of science history which holds that all truth is relative and conditioned by the culture of time and place, for there is nothing fugitive about the structure of DNA or haemoglobin.

Perhaps it was his impatience with the rhetoric of soft disciplines and his insistence on intellectual rigour that drew Perutz into the most unequivocal of scientific pursuits. The crystallographers established an ascendency over chemists from the outset. When the Braggs solved the crystal structure of sodium chloride, Henry Armstrong, a prominent and highly vocal chemist, erupted in Naturein a spluttering paroxysm of affronted professional pride. His invective, which bore the title "Poor common salt", pronounced that no one with an ounce of chemical education could have put forward such a monstrous absurdity as a molecule that was not a molecule. Bragg himself told of how, at the end of a lecture, a chemist approached him to ask whether he might not see his way to moving the sodium atoms in the crystal even the tiniest bit closer to one or other chlorine.

Perutz's demolition of a revisionist biography of Pasteur, which derogates the man and his achievements, is magisterial (although it should be said that in the subsequent exchanges in the New York Review of Books he did not have it entirely his own way); and his analysis of a meretricious account of nuclear waste management in Britain is crushingly informed and incisive. In a sympathetic review of Ruth Sime's biography of Lise Meitner (whom he befriended in her old age in Cambridge), he nails the feminist canard that Otto Hahn deliberately sought to diminish her contribution to the discovery of nuclear fission and magnify his own.

Perutz also records the injustice done to Albert Schatz, who was robbed by Selman Waksman (to whom a misplaced Nobel prize eventually accrued) of the credit for discovering actinomycin. He is a mite hard perhaps on Andrei Sakharov for willingly working on the Soviet hydrogen bomb, and is not altogether correct in the assertion that Sakharov and his colleagues lied when they reported that they had achieved fusion in their first hydrogenbomb test. Richard Rhodes in his definitive account, Dark Sun, states that $15-20 \%$ of the total yield came from fusion, compared with $24 \%$ from the first American thermonuclear device, exploded eight months earlier, with an admittedly much bigger bang.

A trifling distortion also occurs in the review of Hans Krebs's memoirs: the epic paper by Krebs on the citric acid cycle was not exactly rejected by the editor of Nature, Sir Richard Gregory, relying too confidently on his own scientific judgement. Rather, the editors of Nature presented their compliments to Krebs (as was their wont in those more courtly times) and begged to inform him that the Letters section of the journal was for the present fully supplied, but he was welcome to try his luck again a few months later.

Perutz remarks that, for all Krebs's loyalty to Britain, which had given him shelter in a time of need, he remained ponderously Prussian in manner. Few Englishmen, he thinks, could have made such a sententious show of their upright principles as Krebs does in his memoirs. When in 1949 Perutz's student Francis Crick demolished a cherished conjecture about the structure of haemoglobin, he [Crick] would scarcely have solemnly recorded that he had acted "honestly, in good faith and in a spirit of helpfulness" (Krebs's words), rather than, as Perutz puts it, "admitting to a certain mischievous satisfaction in the dastardly deed". I can certainly confirm that, like the Bible, Krebs's book is unsullied by any trace of humour from first to last. And when Krebs asserts that he was not in the least discomposed by a false rumour that he had won a Nobel prize, Perutz recalls his own feelings at a time when similar rumours began to circulate in his laboratory. One day, two telegrams were delivered to the lab, one for John Kendrew and one for himself. But they turned out to be an enquiry about how many reprints they would require of a paper read at a recent conference. "We also," he confesses, "pretended to a stoic calm".

Many of these pieces were first published in the New York Review of Books, but I enjoyed them even more the second time than the first. Perutz's extraordinary historical grasp and the breadth of his personal experience and cultural perspective give his reviews an interest that often transcends that of the books themselves. He brings luminously to life such figures as Fritz Haber, Lise Meitner and Leo Szilard. He writes with wonderfully lucid precision about science and offers also a fine polemic, first read to the American Philosophical Society, on the meaning of freedom. The copy-editors might have done a better job of checking names, and I wonder whether the opera-loving Peter Medawar could really have alluded to Verdi's Faust? This, though, is a wholly captivating book; it has warmth, wit and style, and not a dull sentence. I urge you to read, enjoy and learn.

Walter Gratzer is at the Randall Institute, King's College London, 26-29 Drury Lane, London WC2B 5RL, UK.

\section{Chemistry gallery}

\section{Molecules at an Exhibition: Portraits of Intriguing Materials in Everyday} Life

by John Emsley

Oxford University Press: 1998. Pp. 250.

$\mathfrak{E} 18.99, \$ 25$

\section{István Hargittai}

Marcel Berthelot once pointed out that chemistry resembles the arts. It is unique among the natural sciences in that it creates most of its objects by synthesis. The exhibits in this book include both natural and 